ROCZNIKI TEOLOGICZNE

Tom LXVIII, zeszyt 6 - 2021

DOI: https://doi.org/10.18290/rt21686-2

REV. EDWARD JARMOCH

\title{
RELIGIOSITY OF THE SLOVAKIAN ROMA
}

\begin{abstract}
Religiosity of the Romani has been shaped by their history, which occupies an important role in their social identity. It manifests itself in the dominant religion of the country they live in, whether Lutheran, Catholic, Orthodox, Muslim, or other. The aim of this article is to analyse and present religiosity of the Romani in Slovakia in terms of its basic parameters (faith and beliefs, religious knowledge, religious practice, opinions and moral behaviour). The article is based on the results of the social studies performed in 2018 by Reverend Martin Majda, a professor at the Institute of Theology at Catholic University in Ružomberok. The majority of the Romani in Slovakia belong to the Roman Catholic Church. Their religiosity can be characterised by a specific interpretation of the truths of the faith, e.g. a greater belief in God rather than in the last things. What is more, it bears the traits of folk religiosity, incorporating elements of individual beliefs and rituals, reflecting the Romanis' ethnic origin. Although knowledge is not a sine qua non of identifying oneself with a particular faith, it correlates with religiosity and is worth studying. A great role is attributed to obligatory religious practices, realised on Sundays and during Holy Days, as they affect religiosity of the Romani. There is a diversity of opinions concerning religious morality. What is challenged are the norms of morality adhered to by married couples and families, especially the norms related to human sexuality.
\end{abstract}

Keywords: Roma religiosity; beliefs; religious practices; moral behaviour.

\section{INTRODUCTION}

Present in every culture and society, religion is a significant social phenomenon. Sociology does not explain where religion came from or what its essence is, but treats it as a social fact. It interprets and broadens the knowledge about religion, focusing on its impact on social relationships and social cohesion that bonds different groups.

Religion constitutes an institutionalised system of specific cultural values in secular society. Those cultural values provide basic standards for human

Rev. prof. dr hab. EDWARD JARMOCH - Catholic University in Ruzomberok, Faculty of Theology in Košice, Institute of Theology in Spišská Kapitula (Spišské Podhradie), Slovakia; e-mail: edwardzygmunt@poczta.fm; ORCID: https://orcid.org/0000-0002-8351-9830. 
behaviour, affecting the social system through institutionalised norms regulating social interaction. Social interaction in turn affects personality by internalising culture models. Defined this way, religion includes both personal and socio-cultural aspects. ${ }^{1}$ The internalised values manifested in the attitudes and behaviours of religious communities can be called religiosity. In the public sphere religion can be also regarded as a set of cultural norms and a part of social reality. Thus, faith, norms, values, and religious practice are structural elements of religious systems. Additionally, religious knowledge has its own connection with faith and can increase the latter's intensity.

The religiosity of the Roma has been influenced by various circumstances, factors, and conditions. As a result, its various forms, manifestations, and, above all, its specificity can be observed. The guidelines for Roma pastoral care clearly state that "the history of the Roma is filled with persecution, exile, disapproval and even rejection, suffering, and discrimination, and has developed into a constant journey that distinguishes Roma people from others and keeps them in a nomadic tradition, [...]. In this way, their completely independent identity has been created: with their own culture, language, religiosity, and customs, with a deep sense of belonging to a particular community and strong ties with other members."

Based on the research of Fr Martin Majda PhD, the Theological Institute in Spišská Kapitula of the Catholic University in Ružomberk, this paper focuses on faith and beliefs in the consciousness of the Roma in Slovakia, on their religious knowledge and practices, as well as on selected moral behaviour. The research was conducted in 2018 among Slovakian Roma but also among priests serving pastorally and dealing with issues related to the paper's topic. Taking religiosity parameters into account, the following issues are discussed: Roma faith and beliefs (1), religious beliefs (2), religious practices (3), opinions and moral behaviour (4).

\section{ROMA FAITH AND BELIEFS}

As a parameter of religiosity, faith has undergone one of the more significant systemic changes in Slovakia since the early 1990s, after the fall of communism and political system change. On the one hand, there has been a revival in the approach of believers to faith and to religious values, but on the other

\footnotetext{
${ }^{1}$ Władysław Piwowarski, Socjologia religii (Lublin: Redakcja Wydawnictw KUL, 1996), 43-44.

${ }^{2}$ Pápežská rada, "Smernice”, 27.
} 
hand, in everyday life there has been a great impact of consumerism, combined with the material perception of the world around.

Faith is part of the Christian life of individuals and religious communities. Understood as a declaration of religious affiliation (a declaration of faith), it indicates belonging to a particular religious group. In this sense, it includes not only religious identification, but also self-assessment of one's religiosity, with a view to its further development.

In everyday life, faith is a gift acquired through grace. Although faith is difficult to grasp (it exists primarily on a non-empirical level), it is deeply rooted in the structures of social life. Its expression in social practice can be analysed pastorally and sociologically (on the basis of self-determination and identification). It is recognized as something that is experienced through the heart, accepted as one's own by a person who seeks God. A part of the metaphysical dimension of human existence, it is a peculiar relationship with God, expressed through a person's prayer and sacramental life. It is also Devine Revelation and Tradition extended by the Church to the present times.

Yet, membership of the Church or religious association is not homogeneous, but individual degrees can be distinguished: from formal recognition of belonging to a group, through more or less full acceptance of its objectives and values, to complete and emotional union with the Church, fully following its teaching. Church membership therefore has a wide variety of form and content. ${ }^{3}$

In the sociology of religion, faith is defined as the cognition and recognition of the Absolute, transcendented God. This is manifested in practising religious rites by a person with well-established faith. In addition, faith affects one's observation of ethical laws based on religion. In the catalogue of religiosity parameters, faith is listed first, as a "basic parameter" or "preliminary parameter" also called the parameter of "self-declared faith" or of "self-declared attitude towards faith and religion." 4

Religious self-declaration presents only a rough outline of the importance and role of religion in the lives of individuals and entire societies. This informs only in a general way about the nature and intensity of the attitude towards religion, with little straightforward information on human religiosity. However, by analysing attitude towards self-declared faith, based solely on the self-determination of the subjects surveyed, it is not only their subjectively-declared

\footnotetext{
${ }^{3}$ Janusz Mariański, Kościót w społeczeństwie przemystowym (Warszawa: Instytut Wydawniczy PAX, 1983), 45.

${ }^{4}$ Edward Jarmoch, Religijność żotnierzy zasadniczej i zawodowej stużby wojskowej w warunkach przemian systemowych (Warszawa: Referat Duszpasterstwa Rodzin, 1998), 191.
} 
attitude towards religion that can be studied, but also the intensity of their religion and a degree of their critical reflection. Thus, this paper studying the religiosity of a community is based on the respondents' self declaration, with theoretical and methodological assumptions forming the basis for the analysis of the religious self-identification of the surveyed Roma group.

The first question asked was: To which Church or religious association do you currently belong? It turned out that the vast majority of respondents belonged to the Roman Catholic Church (90.8\%). If a person did not belong to the Catholic denomination (3.1\%), it was assumed that he or she was a member of another Church or religious group. By contrast, $6.1 \%$ of respondents did not know how to answer. ${ }^{5}$

In comparison, according to religious statistics, in 1991, 63.8\% of Slovaks claimed to be Catholic; $0.7 \%$ members of the Orthodox Church; $6.2 \%$ Protestant; $2.1 \%$ other; $9.8 \%$ no religion; $17.4 \%$ did not reply. In 2011 , the population percentage of above religious groups was as follows: $65.8 \%, 0.9 \%$, $5.9 \%, 3.4 \%, 13.4 \%$, and $10.6 \%$, respectively. According to the answers to Yes/No questions, in Slovakia in 1991 there were $88.1 \%$ of religious people (including $77.2 \%$ of Catholics) and $11.9 \%$ of non-believers; in 2001 there were $86.6 \%$ of believers ( $75.3 \%$ of Catholics) and $13.4 \%$ of non-believers; and in 2011 there were $85.0 \%$ of believers (including $73.6 \%$ of Catholics) and $15.0 \%$ of non-believers. ${ }^{6}$

Thus, the Roman Catholic denomination in the studied group was the largest in terms of the number of followers $(90.8 \%)$. This also applies to the whole of Slovakia, where the dominant Roman Catholic faith is a permanent element of national culture and identity.

The in-depth socio-pastoral analysis indicates that Roma consider themselves believers, belonging to the Catholic faith, or they adopt the religion of the country in which they live. Attitudes towards religion, which are often only declarative, must be analysed together with the respondent's motivation for choosing an answer. It is necessary to know, as far as possible, the rationale for his or her faith. Their motivation for faith can be complicated, whether it is their own reflection or cultural heritage obtained from their parents, it results from belonging to a social group, or it originates from other sources.

\footnotetext{
${ }^{5}$ Martin Majda, Špecifiká religiozity Rómov (Spišská Kapitula: Nadácia Kňazského seminára biskupa Jána Vojtaššáka, 2018), 109.

${ }^{6}$ Ondrej Štefaňak, "Religijność młodzieży słowackiej w procesie przemian", Przegląd Religioznawczy - The Religious Studies Review 2(2018): 117.
} 
Although the Roma often equate with the dominant creed in the country, they still retain some of their specific elements. Their faith is frequently a specific symbiosis of Christian beliefs with elements of their own superstitions and customs; it is a manifestation of folk faith. ${ }^{7}$

The influence of the family and religious socialisation on their attitude to faith is also noted. According to the survey, a vast majority grew up as children with the family in a home with sacred images (96.4\%), and only $3.1 \%$ did not have them, influenced, among other things, by other religious groups who had removed them. In addition to attending religion classes at school, $42.9 \%$ of respondents participated in other religious formation activities for less than 5 years, belonging to various parish-organized associations and groups, while $15.3 \%$ participated for less than 10 years, and only $6.6 \%$ of the most persistent ones were active for more than 10 years. ${ }^{8}$ The patterns acquired from the family home are still being cultivated.

\section{RELIGIOUS BELIEFS}

Beliefs are specific religious truths that arise from human cognitive needs and are closely linked to the faith of other members of the group. They contain the recognition of the reality of the non-empirical world and the consequences that result from believing in that world. In the Catholic religion, beliefs take the form of dogmas of faith, from the Greek dogma - a recipe, a set of beliefs that have to be adopted in order to know God. As the Catechism of the Catholic Church teaches, "Dogmas are lights along the path of faith; they illuminate it and make it secure. Conversely, if our life is upright, our intellect and heart will be open to welcome the light shed by the dogmas of faith. The mutual connections between dogmas, and their coherence, can be found in the whole of the Revelation of the mystery of Christ. In Catholic doctrine there exists an order or hierarchy." "The set of dogmas of faith and the system of religious values imposed by the Church on its members are mandatory in terms of acceptance and in terms of religious behaviour.

\footnotetext{
${ }^{7}$ Majda, Špecifiká religiozity, 29; Arne Mann, Vztáah Rómov k viere. In Pastorácia Rómov (Prešov: Petra, 2009), 30; Tatiana Podolinska, "Koho Boh? O kultúrnej aproximácii krest’anstva medzi Rómami na Slovensku," in Pastorácia Rómov (Prešov: Petra, 2009), 73-110; Arne Mann, Rómsky dejepis (Bratislava: Kalligram, 2000), 27.

${ }^{8}$ Majda, Špecifiká religiozity, 106-108.

${ }^{9}$ Katechizm Kościoła Katolickiego (Poznań: Wydawnictwo Pallottinum, 2020; since KKK), 88-90.
} 
An analysis of religious beliefs started with basic questions directly related to the existence of God and eschatological truths. It was assumed that the religiosity of the Roma had its tradition, and that they valued their beliefs directly related to God quite highly, since recognizing God as the highest and most absolute authority should be the guiding and fundamental idea of any religion. Acceptance of other dogmas would depend on the acceptance of this basic truth of faith. As the Catechism of the Catholic Church teaches, believing in God means clinging personally to God by entrusting himself/herself to him completely and acknowledging all the truths that he has revealed, for God is the truth. ${ }^{10}$

Consequently, in the survey the next question the Roma respondents were asked was whether they believed in the existence of God or not. It turned out that the rate of believers was at a very high level $(99.5 \%)$. It is worth highlighting that no one officially questioned the existence of God, and only $0.5 \%$ of respondents could not confirm their faith. ${ }^{11}$

In the Church's teaching, the truths of faith concerning eschatology give the Christians hope of eternal life. The hope is not only in the future, it is also experienced in the present, with a believer striving to seek God. The dogma of eternal life is the culmination of the Christian Creed. It is the duty of the believer to accept this truth and to agree with its content. After death, the human soul is judged by God, and goes either to heaven, purgatory, or to hell.

The belief in hell is present in Roma consciousness to a high degree $(81.1 \%)$, with $6.6 \%$ of them not believing in it. For the latter respondents, such an attitude results in weakening faith and challenging the Church's teaching. One in 20 respondents said there might be hell, while $6.6 \%$ did not provide a definite answer. Thus, it might be concluded that the belief in the existence of hell is strong in the Roma community.

In the consciousness of the Roma a belief in the spirits of the dead is also present $(36.7 \%)$. However, through the sacraments and sacramentalia, people are protected from them, and as a result of pastoral formation, the rate of this phenomenon decreases. Some of them believed that it was necessary to burn a light in the room all the time if the child was not baptized $(49,5)$, or insert a needle, comb, or thread into the baby's pillow (25.5\%), or not to cut the child's hair if he or she is under one year of age $(30.1 \%) .{ }^{12}$ It seems that

\footnotetext{
${ }^{10}$ KKK 150-152.

${ }^{11}$ Majda, Špecifiká religiozity, 107.

12 Majda, Špecifiká religiozity, 114-117.
} 
these superstitions, deeply rooted among some of the Roma people, will be eliminated through long-term pastoral activity.

Martin Majda reports that "there is an opinion among the Roma that all Gypsies will go to heaven, supposedly because they are good people. Although they know about the existence of hell, they have only an inaccurate idea of it. They imagine paradise as a place with no more discrimination, with them being happy and equal there."13

\section{Religious knowledge}

Religious knowledge affects the professed faith and can increase its intensity. Transmitted mainly verbally, it goes quickly into oblivion and its religious content derived from childhood and Religion lessons does not go far beyond a believer's surroundings. However, a low level of religious knowledge can coexist with very intensive religious life.

A lack of deeper religious awareness was common in traditional Catholicism, but in the present conditions of post-industrial civilization it can pose a threat to the ideological dimensions of religiosity. A particularly low level of religious knowledge will not help to solve new problems emerging from the confrontation between traditional Catholicism on the one hand and modernism and post-modernism on the other. Religious knowledge is not subject to radical changes in any social surroundings because it is usually at a low level anyway, but a grasp of basic dogmas is needed to accept and profess the faith. It seems necessary that every Catholic who declares himself/herself a believer should have basic knowledge of the most important truths of faith concerning the Holy Trinity, Jesus Christ, the sacraments, the grace of God, and eternal life. ${ }^{14}$

A question can be asked whether the religious knowledge of the Roma people is sufficient or not. They are often ignorant of religious truths that have no practical meaning to them. In particular, the doctrine of the Holy Trinity or sanctifying grace is too abstract for them. Another problem is that children as well as adults often do not understand the full meaning of abstract Slovak words. Because it is not always possible to convey full religious knowledge

\footnotetext{
${ }^{13}$ Majda, Špecifiká religiozity, 36

${ }^{14}$ Edward Jarmoch, "Wiedza religijna jako intelektualno-poznawczy wymiar religijności”, w Postawy spoteczno-religijne mieszkańców Archidiecezji Szczecińsko-Kamieńskiej, red. Witold Zdaniewicz, Sławomir Zaręba (Szczecin: Szczecińskie Wydawnictwo Archidiecezjalne „Ottonianum”, 2006), 19n.
} 
to the Roma community, they should be at least acquainted with basic truths of faith to deepen their religious consciousness. ${ }^{15}$

Guidelines of the Pastoral Care of Roma of the Pontifical Council for Migrants and Travellers underline the value of religious knowledge. "We can see that by the transmission of basic religious knowledge, combined on a human level with playing, competitions, etc., a deeper relationship with God develops, followed by a personal encounter with Christ and by missionary activity. In their community the next step to be achieved is when the Roma themselves pass on the treasure of faith to other Roma people."16

One of the factors affecting religious knowledge is the sources of its acquisition and broadening, with children participating in school catechesis. To convey the knowledge more efficiently, catechists and pastors use audio-visual resources. "In catechesis, we use creative forms of expression and music, because the proclamation of faith among Roma is based mainly on emotional experience. We conduct catechesis in small groups (divided into boys and girls), at regular times and in their surroundings." 17 Activities that can take the form of dialogues or discussions, with the use of teaching aids, contribute to the acquisition of religious knowledge and its broadening.

In order to determine their level of religiosity and to find out how they understood their faith and how they were familiarised with the Church's teaching, questions about the most essential elements that should be known to every Catholic, regardless of the surroundings and education, were asked. The truth about the essence of the Only God in three Divine Persons was considered to be the most important. "The mystery of the Holy Trinity is at the heart of the mystery of faith and Christian life. Only God revealing himself as the Father, Son and Holy Spirit can allow us to know himself." 18

A question was deliberately asked: Does the Holy Trinity consist of Jesus, Mary and Joseph? According to the research, Roma knowledge of the Holy Trinity was correct at a relatively high level (72.5\%). Only a few of them gave the wrong answer, and none of the respondents replied "maybe.",

\footnotetext{
${ }^{15}$ Majda, Špecifiká religiozity, 37n.

${ }^{16}$ Pápežská rada, ,Smernice”, 100.

${ }^{17}$ František Šarník, Výchova a vzdelávanie Rómskych žiakov ako pedagogický systém: dizertačná práca (Prešov: PU, 2006), 38.

${ }^{18}$ KKK 261.

${ }^{19}$ Majda, Špecifiká religiozity, 113n.
} 


\section{RELIGIOUS PRACTICES}

Religious practices are among the most visible and fundamental components of traditional religiosity. They can be individual and private, as well as collective and public.

In contrast to occasional and not-compulsory religious practices, Sunday and holy day Mass is compulsory. In addition to taking part in religious practices and the frequency of attending Mass, subjective underlying motives are important, and so are the sense and meaning attributed to them and the nature of the experiences and emotional responses. That peculiar link between external behaviour and inner motivations makes it possible to treat those practices as a reliable important indicator of ecclesiastical religiosity.

The participation of Catholics in cult practices, including non-obligatory Mass, is regulated by appropriate religious and ecclesiastical norms. However, it is well known that the norms requiring Catholics to behave religiously can be accepted and judged by them from various points of view. Religious practices are therefore motivated be various factors, not always of religious nature, but the stronger the religious motivation, the greater the chance of the practice being continued.

Five occasional religious services are mainly taken into account: Baptism of a child, first Holy Communion, Confirmation, and church wedding and funeral. All these events not only testify about a Catholic's loyalty to the Church, but also bring about some changes in his or her life and family situation. The sacrament of Baptism is the first step to become involved in the Church as its member. It introduces a child to religious life of the Church as a member of Christian society, while the funeral leads him/her out of this community; the first Holy Communion and the sacrament of Confirmation change a person's position and role in the parish, while the sacrament of marriage introduces a new state of personal life, starting a family. ${ }^{20}$

The first of occasional religious ceremonies is the sacrament of Baptism. It is the foundation of all Christian life and the first step to the other sacraments. Through Baptism, one is liberated from original sin and becomes a member of the Church. Partaking in the sacrament of Baptism ceremony in the consciousness of the Roma is valued very highly, although they do not always understand its theological meaning. For some families, Baptism protects the child from various dangers resulting from superstition. According to other prevailing superstitions, until the child is baptized it is threatened by various

\footnotetext{
${ }^{20}$ Jarmoch, Religijność żotnierzy, 250n.
} 
evil forces, and to protect the child parents practise appropriate customs, including giving him or her an additional name or nickname to deter evil spirits. ${ }^{21}$

The second special ceremony is the first Communion. Although they do not understand the essence of the Eucharist, parents want their children to receive the first Communion after proper preparation. They approach this religious event more spectacularly and treat it as a unique opportunity for family reunion and celebration.

The third special ceremony is the sacrament of Confirmation. Through this sacrament one receives seven gifts of the Holy Spirit, to profess the faith valiantly and to live according to the principles of the Catholic faith. Some Roma do not understand this sacrament well, not least because the idea of the gifts of the Holy Spirit is completely incomprehensible to them. Studies have shown that two thirds of Roma have received of the sacrament of Confirmation and one third of them have not. In this regard religious instruction will deepen understanding of the essence of this sacrament of Christian maturity.

The fourth religious ceremony is a church wedding. It is firmly rooted in Roma culture and tradition and associated with a number of rituals, with each group having different ones, but their essence is usually the same. During the period of engagement, they use magical practices, directed by various superstitions. There have been cases when children have been forced by their parents to marry and they have been told that love will come when they start living together. When they are still very young, spouses generally take over all matrimonial rights and obligations towards the community. Only after a few years of living together do they usually ask for a church ceremony. There are generally no divorces between Roma marriages. According to the pastoral practices of Father Ondrej Porubec, out of the approximately 300 Roma couples whom he prepared, also dealing with the canonical obstacles to marriage between close relatives, only three marriages divorced. ${ }^{22}$

The fifth and final ceremony is a funeral in accordance with the Church's tradition in funeral rites. The Church celebrates it in light of the Paschal Mystery and prays that those who, through Baptism, are incorporated into the death and resurrection of Christ, can pass from death to life with Him. They must undergo the purification of the soul so that they can be received among

\footnotetext{
${ }^{21}$ Majda, Špecifiká religiozity, 45n.

${ }^{22}$ Ondrej Porubec, Právne zásady a organizácia dušpastierstva Cigánov na Slovensku: rigorózna práca (Lublin: Katolicki Uniwersytet Lubelski, 1998), 88; Pavol Anatol, "Rodinné obyčaje Rómov v obci Sol'," in Neznámi Rómovia (Bratislava: ISTER SCIENCE PRESS, 1992), 167; Anna Skokanová, Interferenčné vplyvy pôsobiace na komunikačné kompetencie rómskych žiakov so špeciálnymi edukačnými potrebam (Bratislava: Sapientia, 2012), 23.
} 
the saints in heaven. The Church makes a Eucharistic sacrifice for the dead and prays for them. ${ }^{23}$

In particular, the sacrament of the anointing of the sick in the Roma community is very rarely practised, and its essence is not understood. Death is also intertwined with many superstitions among Roma Christians. They fear it, especially the spirits of the dead, and believe in various signs of impending death. On the other hand, they value the presence of the priest at the funeral and consider it an important service given to the deceased. "Loud crying occurs especially when the dead are lowered down. The Roma explain this by saying that if they did not cry and not rush to the grave after the deceased, it would mean that they did not like him or her. For a year, as a sign of mourning, the family of the deceased are not allowed to hold any celebrations or attend any receptions." 24

In general, it can be concluded that the rate of religious practice in Roma families is at an average level. However, some of the above practices are not celebrated even if some are compulsory every Sunday and on holy days and are important in the religious life of Catholics as members of the parish community, but also as believers in Christ. Although Baptism has included the Roma in the Church and made them believers, it is only systematic participation in religious duties that activates their membership in the Church.

The Eucharist is a sacred activity, accompanied by various signs and symbols that introduce the believers to a religious experience, shaping their identity and spiritual development. Participation in Sunday Mass and reception of Holy Communion are among an obligatory part of religious life. It is an injunction, resulting from the first commandment of the Church: "Attendance at Mass on Sundays and Holy Days of Obligation," and those "who voluntarily neglect this duty commit a grave $\sin .{ }^{, 25}$

When discussing mandatory practices, the state of "dominicantes" (Sunday Mass attendance) of Roma families was studied. Empirical material on Sunday Mass attendance was collected on the basis of another group of respondents. They were asked the following question: Do you go to Mass at least every Sunday? The studies showed that the rate of practicing was at a constantly high level (71.4\%). In addition to those going to church every Sunday, there is a category of Catholics practicing occasionally $(9,7 \%){ }^{26}$

\footnotetext{
${ }^{23}$ Józef Wysocki, Rytuat rodzinny (Olsztyn: Warmińskie Wydawnictwo Diecezjalne, 1981), 285.

${ }^{24}$ Majda, Špecifiká religiozity, 56-57.

${ }^{25}$ KKK 2180.

${ }^{26}$ Majda, Špecifiká religiozity, 111.
} 
From the point of view of Roma religiosity, high mass attendance is regarded as a positive criterion confirming their Christian devotion and Church membership. In sociological research on religious practices, however, more attention is paid to quantitative rather than qualitative aspects. Attending a Sunday Mass is not only a fulfilment of an obligation, but a regularly revival of Church membership. Catholics who do not comply with compulsory religious practices on the formal side are still members of the Church, but of their own volition do not want to systematically maintain union with it.

A significant practice related to Mass attendances is the participation in Confession and Communion. Confession is another mandatory religious practice, the fulfilment of which is a result of belonging to the Catholic Church. It cleanses man of sin that has wounded God or the community of the Church. Christ has given the power to forgive sins to the Church, and continues his work by transmitting the Father's forgiving love: "Receive the Holy Spirit; to whom you forgive sins they will be forgiven and to whom you will not forgive them, they will remain unremitted" (Jn. 20:22-23).

At least once a year around Easter, the believer is obliged to confess and receive Holy Communion. Easter Communion is, next to Sunday Mass, a criterion of the religious vitality of Catholics. The attitude of the Christians towards the faith and to practices plays an important role in their decision to participate in Confession and in Mass. Therefore, an important indicator of religiosity is the frequency of Confession, which is associated with another mandatory practice, the reception of Holy Communion. ${ }^{27}$

Respondents were asked: Do you go to Confession at least once a month? It turned out that $72.4 \%$ of those surveyed partook in the sacrament of penance once a month. It should be assumed that the deeper the faith, the more often one confesses his/her sins. By contrast, one in five people went to Confession irregularly and $7.1 \%$ of respondents sometimes. ${ }^{28}$ Overall, a high rate of Roma community participating in the Sacrament of Reconciliation was noted.

Non-mandatory religious practices, especially private ones, are also an important indicator of religiosity. The types of none-compulsory practices varies greatly - from public to private, from general celebrated by the whole Church to regional, and from strictly religious to customary and social. All these practices may take on some cultural, national, or local meaning. ${ }^{29}$ They

\footnotetext{
${ }^{27}$ Edward Jarmoch, "Praktyki religijne i zwyczaje w rodzinie," in Postawy religijno-spoteczne mieszkańców archidiecezji białostockiej, red. Rafał Lange, Wojciech Sadłoń (Białystok: Wyd. św. Jerzego, Instytut Statystyki Kościoła Katolickiego SAC , 2013), p. 37- 59.

${ }^{28}$ Majda, Špecifiká religiozity, 112.

${ }^{29}$ Jarmoch, Uwarunkowania środowiskowe, 241.
} 
are also an expression of intensive religious faith, a helpful resource for a better life, and can be proof of religious vitality. They arise from the attitudes and personal needs.

For the analysis of the religious life of an individual, a private prayer was chosen, which in each religion is the basic act of worship and conversation with God, creating a personal contact between God and man. It is said individually or with the family. That is why the next question the respondents were asked was, "Do you pray every day?"

It turned out that $60.2 \%$ of those surveyed prayed every day, one in five people did not pray systematically, and the same number of people said that they did sometimes. ${ }^{30}$ Individual prayer, understood as a daily prayer, is regarded by believers as an elementary religious duty of a Catholic and has become an important, sometimes the only element of the religious education of children in the family. They usually pray in Slovak, accentuating their emotional experience very strongly. They want God to bestow his love and forgiveness upon them. Prayer accompanies them in their daily lives and is necessary for growing in faith. In turn, strengthened by the prayer, their faith becomes more mature and, transforming their hearts, opens them up to the Church.

In general, it was found that the daily prayer was regarded by a significant proportion of Roma families as a sign of piety, a model for individual faith and manifestation of religiosity, reflecting their attitudes towards religion. The role of the family in the field of religious life is also reflected in the frequency of prayer. Furthermore, the atmosphere of the family home and the worship of religious images there affect a person's attitudes to prayers.

\section{OPINIONS AND MORAL BEHAVIOUR}

In religiosity studies, the parameter of morality is becoming increasingly present. Morality in everyday life is a consequence of religious faith. In religious terms, morality is a number of norms and principles that the Catholic Church formulates in its moral code and expects believers to respect in the structure of daily morality. The set of norms and principles of conduct forming the code creates a model of morality that becomes well established in a given religious community. ${ }^{31}$

\footnotetext{
${ }^{30}$ Majda, Špecifiká religiozity, 110.

${ }^{31}$ Jarmoch, Religijność żotnierzy, 285.
} 
When analysing moral values and behaviours of the Roma, the specificity of this group, resulting from its very nature, should be also taken into account. The fundamental problem in analysing the indicators of moral behaviour and attitudes among the Roma community boils down to the question of whether, or if, their conduct is in line with the moral model of the Church. Due to the compact system of values and moral principles, this model is the same throughout the Catholic Church. Discussing religious morality, the Decalogue is presented in this paper as a universal code of ethics. In particular, the principles of Catholic sex ethics and social justice are also presented.

The Decalogue is ten fundamental moral laws that God, the Creator, has given to people so that they can come to the fullness of their personal development. By following these laws, a human being grows in humanity, and by denying them he or she might be degraded. The commandments are formulated in the form of instructions, injunctions, or prohibition. Their form emphasizes the authority of God talking to man; carrying universal meaning the Decalogue surpasses the authority of any human legal institution. Those ten 'words' are ten paths opened to human life. Proclaimed as the word of God, the Decalogue is also the voice of conscience, a verbalization of natural law imposed on the human being to follow. ${ }^{32}$

The first three commandments governing man's relationship to God have a vertical dimension, while the other seven govern man's relationship with other people in a horizontal dimension. In this paper, the horizontal dimension that relates to the relationship between people is discussed.

The closest neighbours to honour are father and mother, from whom the commandments of the second part of the Decalogue begins. God's fourth commandment, "Honour thy father and thy mother, so thou may live long in the land the Lord thy God is giving" (Ex. 20:12), requires that religious honour should be given to parents anytime and anywhere. This honour stems from the fact that parents are an instrument of God in the transmission of life, of which God is the sole Giver and exclusive Lord. Love and gratitude should also be shown to ancestors and grandparents. ${ }^{33}$

The Roma attach great importance to the family, which is of great value to them, providing protection in need and ensuring safety. The biggest punishment for them is to be removed from the family. Mother and father, as well as the

\footnotetext{
${ }^{32}$ Roman Krawczyk, Dekalog. Kodeks etyki społecznej Starego Testamentu (Siedlce: Wydawnictwo Diecezjalne, 1994), 22-23.

${ }^{33}$ Edward Jarmoch, "Dekalog jako uniwersalna droga postępowania człowieka," in Dzieje-filozofia-życie, red. Edward Jarmoch (Siedlce: Uniwersytet Przyrodniczo-Humanistyczny, 2011), 369-378.
} 
elderly, enjoy great respect from their children and their surroundings. Parents, because of their authority in the family, repeatedly choose a husband for their daughter. In general, the youngest son tries to support his parents; it is rare to place old people in a retirement home. ${ }^{34}$

The other commandments of the Decalogue uphold the fundamental values of life, marriage, and people's property. The fifth commandment, "Thou shalt not kill," in its content means respecting other people's health and life. Among temporal goods, life has the highest value, for once lost it is not recoverable.

The Lord Jesus, too, in the Sermon on the Mount, refers to the Old Testament commandment "Thou shalt not kill" by expanding its scope. It extends it to all manifestations of hatred, violence, and anger that might lead to murder. ${ }^{35}$ On behalf of the whole Church, John Paul II condemned all these crimes and attacks against human life (Evangelium vitae, 5), and the Catechism of the Catholic Church clarifies the transgressions against the Fifth Commandment. These are: murder, non-assistance to a person in danger, termination of pregnancy, euthanasia, and suicide. ${ }^{36}$

There are generally no direct killings among Roma. However, especially in affect and in anger, they show insufficient self-control, accompanied by screams, curses, or profanity. In general, cases of abortion and contraception are not frequent, especially because of the great respect for human life. Yet there are some cases of contraception use, especially among young people.

Many Roma people have health problems; they do not take enough care of their health and do not follow the doctor's recommendations. They do not always lead a healthy lifestyle either. Most of them are not wealthy, and their low standard of living, poor health, and polluted environment increase the danger of infections and diseases. Alcohol abuse and smoking are also a problem. This becomes more frequent when social benefits are paid. ${ }^{37}$

\footnotetext{
${ }^{34}$ Martin Majda, Špecifiká morálky Rómov (Spišská Kapitula: Nadácia Kňazského seminára biskupa Jána Vojtaššáka 2019), 39n.; Porov. František Hanobík, Rómovia, zvyky, tradície, rodina, cirkev (Košice: Arcidiecézne katechetické stredisko, 2003), 15; Porov. Monika Štrbová, Denisa Selická, Rodinné a medzigeneračné väzby v súčasnej rómskej rodine (Katowice: Studio Noa, 2014), 147; Porov. Anna Nemcová, Sociálna starostlivost' o Rómov v Roškovciach zo strany Cirkvi $a$ štátu: dizertačná práca (Ružomberok: KU, 2015), 49.

${ }^{35}$ Henryk Józef Muszyński, Dziesięć stów. Pytania wspótczesnego człowieka o Dekalog (Gniezno: Wydawnictwo Prymasowskie GAUDENTINUM, 1995), 104.

${ }^{36}$ KKK 2258.

${ }^{37}$ Martin, Špecifiká morálky, 41n. Porov. Štrbová, Selická, Rodinné a medzigeneračné väzby, 46; Porov. Peter Bešenyei, Dedičstvo dona Bosca a jeho využitie v rómskej misii. In Preventívny systém v rómskom svete (Bratislava: Don Bosco, 2010), 47; Porov. Dušan Šlosár "Rómovia," in Zmena
} 
The next two commandments, the sixth "Thou shalt not commit adultery" (Ex 20:14) and the ninth "Thou shalt not covet thy neighbour's wife." (Ex. 20:17) stand up for the institution of marriage, ordained by God. In the Old Testament, the prohibition of adultery only forbade intercourse with a neighbour's wife, with a girl already engaged, and with a slave girl intended for another man. In the first two cases, violation of this prohibition was punishable by death and in the last one by fine and by obligation to make a sacrifice. Because of the admissibility of polygamy, a married man did not commit adultery if he was in contact with another free woman. On the other hand, a woman who was married if she lived with another man was always guilty of adultery. Adultery was a transgression that destroyed the unity and authority of the family. It was a crime, by reason of its social consequences, for it undermined the common good and the good of others. ${ }^{38}$

The problem of adultery was also taken up by the Lord Jesus. "You have heard that it was said 'do not commit adultery'! And I say, anyone who even looks at a woman with lust has already committed adultery with her in his heart" (Mt 5:27-28). He firmly rejects the possibility of divorce, restoring to marriage its original and inseparable character, elevating it to the dimension of the dignity of a sacrament.

In the Catechism of the Catholic Church, all issues related to the content of the sixth and ninth commandments are presented in the light of the dignity of a person and the holiness of the family. This includes the basic objectives of marriage: community building, service to life, vocation to chastity, and excludes sins against holy matrimony: promiscuity, masturbation, fornication, pornography, prostitution, rape, and homosexuality, as well as those against the dignity of marriage: adultery, divorce, polygamy, incest, and cohabitation. ${ }^{39}$

In traditional Roma families strict rules of chastity are observed. A Roma girl and boy are not allowed to kiss in public. Nevertheless, the first sexual experiences begin at a young age of about 13-14. When their parents allow it, then young people begin to lead a "married" life together. Then, from the moment of the wedding ceremony, the girl can live together in the house of the boy's parents, and generally they no longer live separately. The manner of wedding ceremony has changed over time and it is a family ritual. Usually, it is only after a few years of life that they enter into a sacramental marriage,

a budúcnost', či stagnácia a minulost' Rómov na Slovensku (Košice: Technická univerzita, 2009), 14. Porov. Nemcová. Sociálna starostlivost’o Rómov, 59.

${ }^{38}$ Marian Filipiak, Problematyka społeczna w Biblii (Warszawa: Instytut Wydawniczy PAX, 1985), 220.

${ }^{39}$ KKK 2351; 2359. 
which entitles them to the baptism of children. They generally marry somebody in their own community; rarely do they marry a non-Roma person. The conjugal bond increases after the birth of the child. They are very sensitive to the sin of adultery, which is still considered one of the most serious crimes in marriage. ${ }^{40}$

After examining the commandments that protect life and marriage, the seventh commandment will be dealt with, defending someone else's property: "Thou shalt not steal" (Ex. 20:15). The Hebrew term "ganab" means not only to steal, but also to rob, abduct, or mislead. This commandment prohibits not only ordinary theft, but also any fraud by which the neighbour's property is acquired. The basic idea of the biblical prohibition of theft is the belief that every person has the right to private property, which is the result of natural law. ${ }^{41}$ The New Testament also confirms the prohibition of theft. Thieves, robbers, and greedy alongside debauchers, adulterers, idolaters are those who do not enter the Kingdom of Heaven ( Eph. 4:27).

The seventh commandment is also valid nowadays, both in its original idea (stealing people and enslaving them), and in a broader sense (theft in general). The validity of this commandment is confirmed by the Catechism of the Catholic Church: "the Seventh Commandment forbids unjustly taking or keeping the goods of one's neighbour and wronging him in any way with respect to his goods." 42

In general, theft in the Roma community is perceived negatively, but is the most common offence among them. It is mainly theft of items in shops and homes and stealing wood or agricultural crops. However, these are generally minor offences.

It happens that with parental consent, children also steal small things, which is seen as a certain dexterity and ability justified by the need to maintain the family and to provide for its members. However, they cannot always manage money skilfully. On the day of social benefit payment, or in a few days after that, they can spend up to $60 \%$ of the money, which forces them to take out loans from loan sharks or other people to whom they rarely return money. Another problem is the dependence of some people on games of

\footnotetext{
${ }^{40}$ Martin, Špecifiká morálky, 44n; Porov. Peter Ružbarský, František Čureja, Duchovný svet Rómov (Prešov: Vydavatel'stvo Michala Vaška, 2004), 50-51; Hanobík, Rómovia, zvyky, tradície, rodina, cirkev, 16; Peter Ružbarský, Situácia a perspektíva sviatostnej katechizácie Rómov (Košice: Vienela, 2009), 133.

${ }^{41}$ Jarmoch, "Dekalog jako uniwersalna droga postępowania człowieka." 369-378.

${ }^{42}$ KKK 2401.
} 
chance and slot machines. Sometimes they lose money and have no food to eat, with the situation forcing them to rob even their own family. ${ }^{43}$

Another value protected by the Decalogue in its eighth commandment is truth: "Thou shalt not bear false witness against thy neighbour." The Catechism of the Catholic Church includes false testimony and perjury, hasty judgments, aspersion, slander, flattery, vanity, and lying among the transgressions against God's eighth commandment. ${ }^{44}$

Lies also happen among Roma as some of them have weak will and do not always keep their word. It is difficult for them to admit their mistake, which results in many lies or excuses. It is also impossible to avoid the issue of oath. Roma often swear by everything possible, because they do not always trust each other, but perjury is seen as one of the worst sins, subject to the almost immediate punishment of God. ${ }^{45}$

The tenth and last commandment of the Decalogue, "Thou shalt not covet anything that belongs to thy neighbor," is a continuation and extension of the ninth commandment referring to the lust of the flesh. A person is warned against being too involved in the attitude of 'having' instead of 'being' .

Another test of a person's moral attitudes is their respect to parents. To study this, a question was asked: If your parents told you to do something immoral, should you do that? Research showed that there was no uniform position in this regard, with $78.1 \%$ of the respondents answering no, $15.8 \%$ saying yes and $4.5 \%$ choosing the answer 'sometimes' ${ }^{46}$ There was no uniform standard in this regard, and as many as $66 \%$ of the respondents approved of the situation in which parents forced their daughter to marry a boy she did not like.

In moral research, much space is usually devoted to analysing society's attitude to Catholic sexual ethics. It is assumed that the influences of modernism and post-modernism have in many respects called into question a number of previously indisputable and widely accepted norms of Catholic sexual ethics. The actual sexual ethics and normative sphere of religion, which regulate sexual problems, have become two different areas, often isolated from each other and not subordinate to each other. The moral attitudes of Roma towards Catholic sexual ethics will be discussed here using example of several selected social norms.

\footnotetext{
${ }^{43}$ Martin, Špecifiká morálky, 48-51; Porov. Peter Ružbarský, Situácia a perspektíva sviatostnej katechizácie Rómov (Košice: Vienela, 2009), 133.

${ }^{44}$ KKK 2475-2486.

${ }^{45}$ Martin, Špecifiká morálky, 52-55; Porov. Podolinská, Koho Boh?, 95.

${ }^{46}$ Martin, Špecifiká morálky, 59.
} 
In the Romani custom, after the so-called "mangavipen," young people begin to officially live as spouses even though they have not had a church wedding. Catholic ethics take the view that any cohabitation before marriage, even in the final stage of premarital courtship, is morally wrong and not allowed. However, $36.2 \%$ of respondents supported this practice, but $60.7 \%$ were against. Most of them $(79.1 \%)$ were aware that such a practice without a church wedding did not please God, with $10.7 \%$ of the respondents being of the opposite opinion and $4.1 \%$ choosing the answer "maybe." ${ }^{, 47}$ The bride and groom have the right to show affection, but its signs should be sexually pure, i.e. it must not be a search for sexual sensations. Bodily inviolability, called virginity, preserved consciously for marriage, is a gift of love and a foreshadowing of love and fidelity during marriage. According to Catholic ethics, only sacramental marriage entitles the husband and wife to sexual intercourse.

The next problem concerns the termination of pregnancy - the murder of a person before his or her birth. The ban on pregnancy termination was already formulated in one of the oldest old Christian works called Didache, the Teaching of Twelve Apostles, originating in the 1st century after Christ. Human life begins at conception, which is why it must be particularly protected from that moment on. The conceived child is not only the result of the interaction of man and woman, but above all the fruit of the creative act of God, who, at conception, calls him or her to the dignity of God's child. On the basis of Catholic morality, there is no case that could justify termination of pregnancy - even if childbirth threatens the life of the mother.

Studies have shown that the norm prohibiting abortion in the minds of $80 \%$ of respondents is in line with the teachings of the Church. Only $10.7 \%$ of them were in favour of the acceptability of pregnancy termination and $3.6 \%$ answered 'it depends on the situation. ${ }^{48}$ In comparison, a 2016 survey of Slovak youth found that $47.3 \%$ of respondents believed that abortion should not be allowed. ${ }^{49}$

Catholic ethics states that abortion in all circumstances is morally wrong and prohibited. In the light of that, there is no justification for pregnancy termination such as: the mother's health risk, difficult material conditions, too many children, rape, or an unplanned child.

The next issue concerns standards that prohibit violations of someone else's property. It was difficult to formulate a question in such a way as to

\footnotetext{
${ }^{47}$ Martin, Špecifiká morálky, 59.

${ }^{48}$ Martin, Špecifiká morálky, 61.

${ }^{49}$ Štefaňak, "Religijność młodzieży słowackiej w procesie przemian”, 126.
} 
distinguish the difference between theft from public property and theft from private property. Therefore, respondents were asked the following question: Is it possible to get fire wood from someone else's woods in the winter?

It turned out that wood theft in the winter was considered by $41.1 \%$ to be allowed, $46.4 \%$ of those surveyed said the opposite, and one in ten people said 'perhaps'. On the other hand, with regard to private property (Is it acceptable to steal wood from a neighbour?), as many as $87.2 \%$ of respondents answered in the negative and only $7.7 \%$ said yes, while $3.1 \%$ said "maybe."

Stealing someone else's property is treated as a violation of another person's rights and as a sin. Although Catholic ethics prohibits stealing from both private and state property, the moral assessments of the Roma are characterised by a certain diversity. In addition to theft, quarrels, disagreements, and alcohol abuse can also be among the negative manifestations of behaviour in the Roma environment. In general, it has been found that there is a weak link between religion and morality in the Roma community.

\section{FINAL REMARKS}

This research investigating Roma religiosity includes an analysis of the results of empirical studies based on religiosity parameters. The parameter of faith expressed in everyday life was treated as "preliminary," while the others, dealing with religious-moral attitudes and behaviour, were also used to study religious life of Roma people.

As regards the self-declaration of faith, the percentage of believers was high, at $90.3 \%$. Some respondents did not consider themselves Catholic $(3.1 \%)$ so it was assumed that they were members of another Church or religion. Additionally, $6.1 \%$ of respondents did not provide a definite answer. Atheistic attitudes were rare, and no one admitted to atheism openly. Thus, Roma people in Slovakia constitute an ethno-religious homogenous group, with a vast majority being members of the Roman Catholic Church; in terms of religious life, most of them were close to God.

The level of religious beliefs varied according to the truths of the faith. Faith in God was declared by as much as $99.5 \%$ of the respondents, $72.5 \%$ of them believed in the Trinity and $81.1 \%$ in the existence of hell. Among the surveyed Roma group, there were some respondents who expressed doubts about some truths of faith or explicitly denied them. It was found that

\footnotetext{
${ }^{50}$ Martin, Špecifiká morálky, 64.
} 
$6.6 \%$ of them questioned the existence of hell. They were particularly doubtful about eschatological dogmas, perhaps because of the deeply-rooted belief in the spirits of the dead $(36,7 \%)$. The doubts about certain truths additionally indicated individual religious attitudes present among the subjects.

Religious knowledge, even if not a guarantor of religious-moral value, but only of mental agility, can have a certain effect on religious life. In the intellectual dimension of religiosity, basic catechism knowledge is necessary. However, religious knowledge of the Holy Trinity, sanctifying grace, and of other religious dogmas is too abstract for some of them. These religious truths, which have no practical meaning to them, are in fact unknown or incomplete. Even if they know those truths, they do not always understand them in terms of correct religious knowledge. An important source of the latter is attending Religion classes at school and bonding with the parish community. The fact that in some cases their religious knowledge is smaller than their acceptance of the truths of faith is indicative of the weakness of the intellectual component of the their religiosity, which needs to be deepened.

In the parameter of religious ceremonies and customs in the family, it should be stated that they attend occasional religious practices. Not all practices are important to them to the same extent. Two of them, baptism and burial, are attended by many of them, others are slightly less popular. The sacramental marriage is greatly delayed due to the cultivation of their customs.

However, their participation in Sunday Mass, so-called dominicantes, was quite high, with $71.4 \%$, with $72.4 \%$ of Roma going to Confession once a month. The religious life of families is not limited to compulsory church attendance, but also to non-compulsory practices and religious customs. Most of them said that they prayed daily (60.2\%), highlighting their emotional experience strongly. By contrast, $20.4 \%$ were in favour of unsystematic daily prayers. A vast majority of children grew up in a family home where the paintings were sacred $(96.4 \%)$. These patterns are further cultivated.

A wide diversity of opinions on the consequential dimension of their religiosity was noted. In general, there is often a lack of conformity between the norms and values they live by and norms and values resulting from religion. Norms related to marriage and family life were mostly questioned, especially those concerning the sexual sphere. Most parents and the elderly enjoyed great respect and obedience from their children and their surroundings.

Sexual purity before marriage was accepted by $10 \%$ and not accepted by $36.2 \%$ of those surveyed, although $79.1 \%$ of them were aware that marriage without a church wedding did not please God. Divorces were rare, and abortion 
was approved by $10.7 \%$ of the respondents. According to $3.6 \%$ of them, it is justified by various circumstances.

Quarrels, disagreements, alcohol abuse and theft are among most common manifestations of moral inertia among the Roma community. The most common theft offences are stealing goods in shops, firewood, or agricultural crops. It happens that children with parental consent also steal small things. Theft of firewood in winter was treated by two-fifths of those surveyed as allowed, and one in ten people said it was allowed sometimes. On the other hand, wood belonging to a neighbour was safe as stealing it should be strongly condemned (87.2\%).

According to the survey, there was only a weak link between religion and morality in the Roma community, with a disharmony between the moral teaching of the Church and the modern mentality of people. This conclusion is based on an analysis of empirical research presented in this paper.

\section{BIBLIOGRAPHY}

Antol, Pavol. "Rodinné obyčaje Rómov v obci Sol'.” In Neznámi Rómovia. Bratislava: Ister Science Press, 1992.

Bešenyei, Peter. "Dedičstvo dona Bosca a jeho využitie v rómskej misii." In Preventívny systém v rómskom svete. Bratislava: Don Bosco, 2010.

Bešenyei, Peter. Rómske ticho. Bratislava: Don Bosco, 2009.

Hanobík, František. Rómovia, zvyky, tradície, rodina, cirkev. Košice: Arcidiecézne katechetické stredisko, 2003.

Filipiak, Marian. Problematyka spoteczna w Biblii. Warszawa: Instytut Wydawniczy PAX, 1985.

Jarmoch, Edward. Religijność żotnierzy zasadniczej i zawodowej służby wojskowej w warunkach przemian systemowych. Warszawa: Referat Duszpasterstwa Rodzin, 1998.

Jarmoch, Edward. "Wiedza religijna jako intelektualno-poznawczy wymiar religijności.” W Postawy społeczno-religijne mieszkańców Archidiecezji Szczecińsko-Kamieńskiej, red. Witold Zdaniewicz, Sławomir Zaręba, 19-45. Szczecin: Szczecińskie Wydawnictwo Archidiecezjalne "Ottonianum", 2006.

Jarmoch, Edward. "Dekalog jako uniwersalna droga postępowania człowieka.” W Dzieje-filozofiażycie, red. Edward Jarmoch, 369-378. Siedlce: Uniwersytet Przyrodniczo-Humanistyczny, 2011.

Jarmoch, Edward. "Praktyki religijne i zwyczaje w rodzinie." W Postawy religijno-spoteczne mieszkańców archidiecezji białostockiej, red. Rafał Lange, Wojciech Sadłoń, 37-59. Białystok: Wyd. św. Jerzego, Instytut Statystyki Kościoła Katolickiego SAC, 2013.

Katechizm Kościoła Katolickiego. Poznań: Wydawnictwo Pallottinum, 2020.

Krawczyk, Roman. Dekalog. Kodeks etyki spotecznej Starego Testamentu. Siedlce: Wydawnictwo Diecezjalne, 1994. 
Majda, Martin. Špecifiká morálky Rómov. Spišská Kapitula: Nadácia Kňazského seminára biskupa Jána Vojtaššáka. 2019.

Majda, Martin. Špecifiká religiozity Rómov. Spišská Kapitula: Nadácia Kňazského seminára biskupa Jána Vojtaššáka, 2018.

Mann, Arne. Rómsky dejepis. Bratislava: Kalligram, 2000.

Mann, Arne. Vzṫah Rómov k viere. In Pastorácia Rómov. Prešov: Petra, 2009.

Mariański, Janusz. Kościót w spoteczeństwie przemystowym. Warszawa: Instytut Wydawniczy PAX,1983.

Muszyński, Henryk Józef. Dziesięć słów. Pytania wspótczesnego człowieka o Dekalog. Gniezno: Wydawnictwo Prymasowskie GAUDENTINUM, 1995.

Nemcová, Anna. Sociálna starostlivost' o Rómov v Roškovciach zo strany Cirkvi a štátu: dizertačná práca. Ružomberok: KU, 2015.

Pápežská rada pre pastoráciu migrantov a cestujúcich. "Smernice pre pastoráciu Rómov". Accessem January 12 2021, https://kbs.sk/obsah/sekcia/h/dokumenty-a-yhlasenia/p/dokumentyvatikanskych-uradov/c/smernice-pastoracia-rom.

Piwowarski, Władysław. Socjologia religii. Lublin: Redakcja Wydawnictw KUL, 1996.

Podolinska, Tatiana. Koho Boh? O kultúrnej aproximácii krestanstva medzi Rómami na Slovensku. In Pastorácia Rómov. Prešov: Petra, 2009.

Porubec, Ondrej. Právne zásady a organizácia dušpastierstva Cigánov na Slovensku: rigorózna práca. Lublin: Katolicki Universytet Lubelski, 1998.

Ružbarský, Peter. Čureja, František. Duchovný svet Rómov. Prešov: Vydavatel'stvo Michala Vaška, 2004.

Ružbarský, Peter. Situácia a perspektíva sviatostnej katechizácie Rómov. Košice: Vienela, 2009.

Šarník, František. Výchova a vzdelávanie Rómskych žiakov ako pedagogický systém: dizertačná práca. Prešov: PU, 2006.

Šlosár, Dušan. "Rómovia." In Zmena a budúcnost', či stagnácia a minulost' Rómov na Slovensku. Košice: Technická univerzita, 2009.

Skokanová, Anna. Interferenčné vplyvy pôsobiace na komunikačné kompetencie rómskych žiakov so špeciálnymi edukačnými potrebam. Bratislava: Sapientia, 2012.

Štefaňak, Ondrej. "Religijność młodzieży słowackiej w procesie przemian”. Przegląd Religioznawczy - The Religious Studies Review 2(2018): 113-127.

Štrbová, Monika, Selická, Denisa. Rodinné a medzigeneračné väzby v súčasnej rómskej rodine. Katowice: Studio Noa, 2014.

Wysocki, Józef. Rytuat rodzinny. Olsztyn: Warmińskie Wydawnictwo Diecezjalne, 1981. 


\section{RELIGIJNOŚĆ ROMÓW NA SŁOWACJI}

\section{Streszczenie}

Religijność Romów została ukształtowana historycznie i zajmuje ważne miejsce w ich tożsamości społecznej. Znajduje ona zwykle wyraz w religii kraju, w którym mieszkają Romowie, czy to luterańskiej, katolickiej, prawosławnej, muzułmańskiej czy innej, często bez zwracania uwagi na różnice między nimi. Celem tego opracowania jest analiza i prezentacja religijności Romów na Słowacji, w jej podstawowych parametrach (wiara i wierzenia, wiedza religijna, praktyki religijne, opinie i zachowania moralne). Podstawowym źródłem tej rozprawy są wyniki badań społecznych przeprowadzonych w 2018 roku przez ks. dra Martina Majdę, profesora z Instytutu Teologicznego w Špiskiej Kapitule Uniwersytetu Katolickiego w Ružomberku. Romowie na Słowacji w zdecydowanej większości przynależą do wyznania rzymskokatolickiego. Ich religijność charakteryzuje się specyficzną interpretacją prawd wiary, np. większa aprobata dotyczy wiary w Boga, a mniejsza w rzeczy ostateczne. Ponadto ma ona znamiona religijności ludowej, połączonej z elementami własnych przesądów i obrzędowości, w których odzwierciedla się tożsamość etniczna. Chociaż wiedza nie jest warunkiem sine qua non identyfikacji z wiarą, to w jakimś stopniu skorelowana jest z religijnością i dlatego konieczne jest jej pogłębianie. Duże znaczenie przypisywane jest praktykom religijnym obowiązkowym, spełnianym w każdą niedzielę i święta, bowiem rzutują one na życie religijne Romów. W zakresie moralności religijnej zauważa się duże zróżnicowanie opinii. Najbardziej kwestionowane są normy moralności dotyczące małżeństwa i rodziny, a szczególnie normy porządkujące sferę seksualną człowieka.

Słowa kluczowe: religijność Romów; wierzenia; praktyki religijne; zachowania moralne. 